\title{
MONITORING OF LINGUISTIC ACTION PERSPECTIVE DURING ONLINE WEEKLY WORK PLANNING MEETINGS
}

\author{
Fabián Retamal ${ }^{1}$, Luis A. Salazar ${ }^{2}$, Luis F. Alarcón ${ }^{3}$, and Paz Arroyo ${ }^{4}$
}

\begin{abstract}
There is a need to improve construction productivity through project planning and control. In this study, the authors measured and analyzed the Key Indicators for Linguistic Action Perspective (LAP) in the Last Planner® System (LPS) through the Lean Implementation Plan (LIP) research method. This research was carried out for four high rise construction projects in different Colombian cities. Some of the most notable results were that the positive LAP indicators increased in three of the four projects during the first five weeks of intervention. In addition, there was a positive trend for all the projects regarding the LAP indicators in the long term. Furthermore, the percentage of plan completed (PPC) stabilized in all projects, improving the level of LPS maturity. The research was successful even though it was performed using online intervention due to the COVID-19 pandemic. Finally, the authors propose future research that focuses on finding other patterns, adding additional variables to the study, and analyzing projects with different characteristics and in other countries.
\end{abstract}

\section{KEYWORDS}

Linguistic action perspective, Last Planner® System, lean implementation, case study.

\section{INTRODUCTION}

The construction industry has not increased their productivity factor, as other industries have (Eastman, Teicholz, Sacks, \& Liston, 2011). Therefore, it is essential to improve the planning and control of projects by standardizing and strengthening the technical and operational capacities of workers (McKinsey \& Company, 2009). As part of the philosophy of Lean Construction, the Last Planner® System (LPS), developed by Glenn Ballard and Gregory Howell in the 1990s (Ballard \& Tommelein, 2016), is the most widely used methodology for the planning, design, and construction of buildings and infrastructure (Babalola, Ibem, \& Ezema, 2019).

1 MSc Student, Department of Construction Engineering and Management, Pontificia Universidad Católica de Chile, Researcher - GEPUC, Santiago, Chile, +56 22354 7165, faretamal@uc.cl, orcid.org/0000-0002-6554-5576

2 PhD Candidate, Department of Construction Engineering and Management, Pontificia Universidad Católica de Chile. Assistant Profesor, Construction Engineering, Faculty of Engineering, Universidad. Andres Bello, Santiago, Chile, +56 22661 8346, lasalaza@uc.cl, orcid.org/0000-0001-7339-8935

3 Professor, Department of Construction Engineering and Management, Pontificia Universidad Católica de Chile, Santiago, Chile, +56 22354 7165, lalarcon@ing.puc.cl, orcid.org/0000-0002-9277-2272

4 Quality Leader, DPR Construction, San Francisco, CA 94111, USA, paza@ dpr.com, orcid.org/0000$\underline{0002-8098-8172}$ 


\section{BACKGROUND}

\section{Last Planner@ System And Linguistic Action Perspective}

The Last Planner® System is a planning and commitment control methodology based on the principles of Lean Construction and seeks to increase the reliability of planning and the performance of construction projects (Ballard \& Tommelein, 2016). According to Goldratt \& Cox (2013), reliability depends on the effectiveness of controlling dependencies and fluctuations between project activities. Therefore, the management and control of commitments become relevant, primarily in weekly work planning meetings (Salazar, Ballard, Arroyo, \& Alarcón, 2018). For this purpose, Macomber \& Howell (2003) propose the Linguistic Action Perspective (LAP), also called "language action," as a way to improve commitment management in construction projects. This perspective, developed by Flores (2015), is based on the application of the speech act theory (Austin, 1971; Searle, 1969). Flores (2015) states that there are four stages involved in "conversation for action" or "commitment management," which are 1) the preparation of a request; 2) negotiation and agreements; 3 ) the execution and declaration of compliance; and 4) the acceptance and declaration of satisfaction (Salazar et al., 2018).

Consequently, Salazar et al. (2018) carried out an initial proposal of indicators to measure and control the management of commitments in construction projects, applying the principles of LAP. Later, after several iterations, Salazar, Arroyo, \& Alarcón (2020) proposed a system of key LAP indicators that measure and control the management of commitments. However, there are still not enough case studies to analyze the relationship between these indicators ant the percentage of plan completed (PPC) and construction project performance.

\section{RESEARCH METHODOLOGY}

The authors selected the case study methodology because of the research questions it asks, how and why (Yin, 2003). Furthermore, this study did not represent a "sample", and therefore a controlled experiment was ruled out (Retamal, Salazar, Herrera, \& Alarcón, 2020). In this case, the authors performed a longitudinal-multiple-holistic case study because this research aims to extend and conceptualize theories through an analytical generalization of causal relationships, both simple and complex, through the verification of the proposed theory (Yin, 2003) and is not a statistical generalization (Yacuzzi, 2005).

\section{Selected Projects}

The authors selected four projects for participation in this research. These projects were all located in Colombia, but in different cities: Barranquilla (Project A), Bucaramanga (Project B), and Bogota (Project C and Project D).

These projects had the same characteristics (tall building type), and they were measured in the same eight weeks. Measurement for each project started on October $13^{\text {th }}$, 2020, and ended on December 08 ${ }^{\text {th }}, 2020$.

Weekly work planning meetings were held in person, with adequate social distancing. Additionally, the meetings were held outdoors, and all participants wore masks. In some cases, a megaphone was used so that all meeting participants were aware of when it was their turn to participate. Only the authors who performed the interventions were remotely located. 


\section{LEAN IMPLEMENTATION PLAN}

The authors used the Lean Implementation Plan (LIP) research method. This method is based on the art and practice study, with 5 phases of implementation (Gómez-Cabrera, Salazar, Ponz-Tienda, \& Alarcón, 2020).

According to Gómez-Cabrera et al. (2020), the first step is the project's characterization, i.e., the authors must understand the project's state prior to implementation. The next phase is to make a diagnosis using KPIs, establishing a baseline for the project. Third, the authors select tools from Lean Implementation to apply to each project. Finally, the project is evaluated, and is considered to have started an improvement process. Figure 1 shows the process implemented in this research.

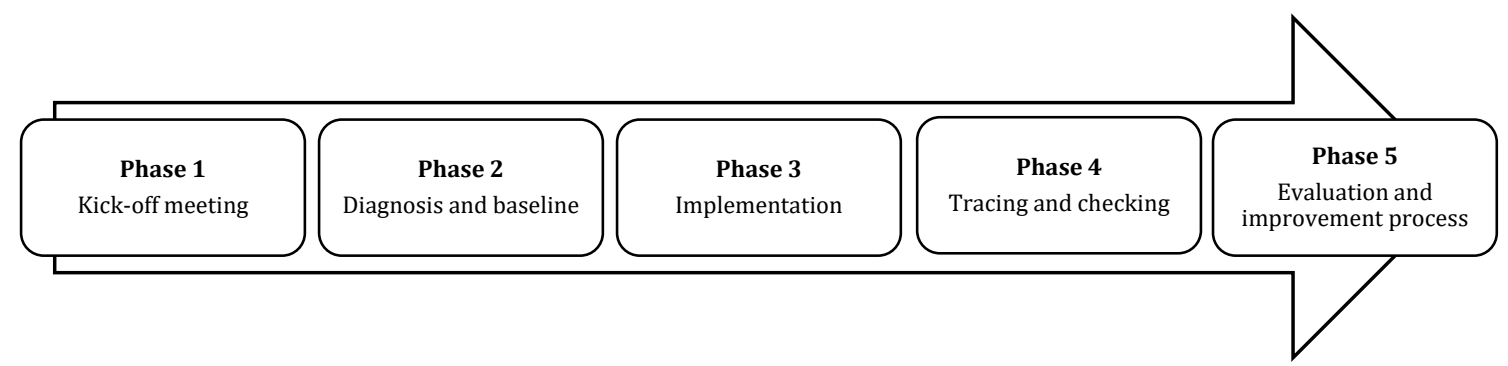

Figure 1: Lean Implementation Plan process (LIP) (Figure 2 in Gómez-Cabrera et al., 2020)

\section{SELECTED INDICATORS}

\section{Last Planner® Maturity}

The level of maturity is defined as the level of depth at which a tool is implemented. This measure depends on the implemented tool type (Vujica Herzog \& Tonchia, 2014).

The Center of Excellence in Production Management (GEPUC) developed a worksheet that measures the level of implementation and maturity of the LPS. This worksheet measures key aspects of the Last Planner ${ }^{\circledR}$ System and allows users to track the level of implementation as well as the different practices involved in this methodology (Baladrón Zanetti, 2017). Figure 2 shows an example of the worksheet used to measure the level of maturity in the LPS. The average of these indicators is the percentage of LPS maturity, and the red color corresponds to a low level of maturity, yellow corresponds to a medium level, and green corresponds to an advanced level of LPS maturity.

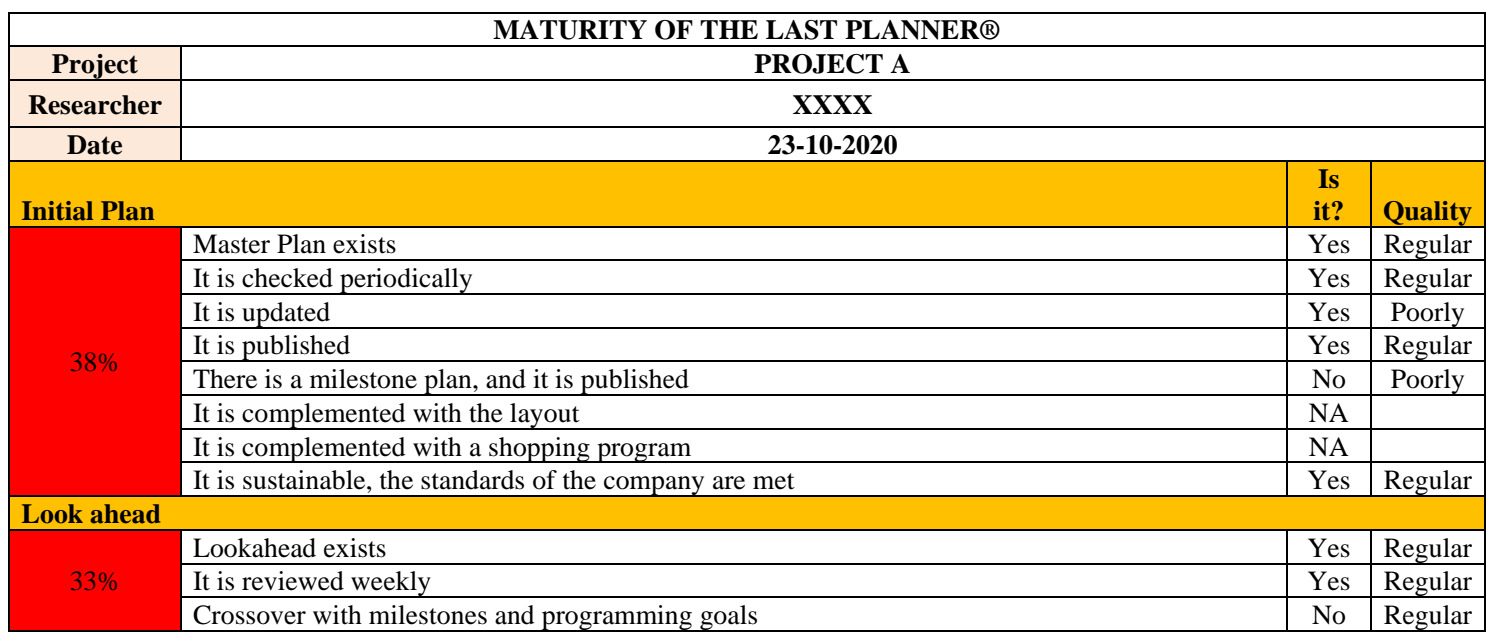




\begin{tabular}{|c|c|c|c|}
\hline \multicolumn{4}{|c|}{\begin{tabular}{|l|} 
Restrictions Management \\
\end{tabular}} \\
\hline \multirow{4}{*}{$50 \%$} & Record of restrictions exists & Yes & Good \\
\hline & It is measured & Yes & Regular \\
\hline & It is tracked & Yes & Regular \\
\hline & There is an indicator for managing restrictions for noncompliance & No & \\
\hline \multicolumn{4}{|c|}{ Weekly Work Planning Meeting } \\
\hline \multirow{5}{*}{$52 \%$} & Be prepared before the meeting & Yes & Regular \\
\hline & The structure of the meeting is followed & Yes & Good \\
\hline & There is the active participation of the Last Planners & Yes & Poorly \\
\hline & It takes place weekly & Yes & Regular \\
\hline & The goal is clear & Yes & Poorly \\
\hline \multicolumn{4}{|c|}{ Causes of noncompliance analysis } \\
\hline \multirow{5}{*}{$75 \%$} & CNC exist in the meeting & Yes & Regular \\
\hline & Accumulated CNC are recorded & NA & \\
\hline & Weekly CNC are recorded & Yes & Good \\
\hline & Weekly analysis of CNC & Yes & Regular \\
\hline & $\mathrm{CNC}$ are published & Yes & Good \\
\hline \multicolumn{4}{|c|}{ Corrective actions } \\
\hline \multirow{3}{*}{$77 \%$} & Corrective actions exist in the meeting & Yes & Good \\
\hline & Corrective actions are recorded & Yes & Good \\
\hline & Its impact is monitored & Yes & Poorly \\
\hline \multicolumn{4}{|c|}{ Reliable commitments } \\
\hline \multirow{3}{*}{$20 \%$} & Commitment by the Last Planner & Yes & Poorly \\
\hline & There is analysis of quantities and resources necessary to achieve the proposed goal & Yes & Poorly \\
\hline & Responsible comes with their own plan proposal & No & \\
\hline \multicolumn{4}{|c|}{ Visual management } \\
\hline \multirow[b]{2}{*}{$0 \%$} & Visual management exists in the meeting & No & \\
\hline & It is updated & No & \\
\hline \multicolumn{4}{|c|}{ Phase plan } \\
\hline \multirow{5}{*}{$40 \%$} & It is done & Yes & Good \\
\hline & It is updated & Yes & Regular \\
\hline & Commitments are recorded & Yes & Regular \\
\hline & It is monitored periodically & No & \\
\hline & Visible panel & No & \\
\hline \multicolumn{4}{|c|}{ Measurement and control of indicators } \\
\hline \multirow{8}{*}{$19 \%$} & Attendance Control Record & No & \\
\hline & Concrete Advance Curve Chart & No & \\
\hline & Key Items Yield Curve Chart & No & Regular \\
\hline & Graph of Yield Curves of Key Items by subcontract & No & \\
\hline & Graph of Compliance with Progress Commitments (PPC) & No & \\
\hline & Causes of Noncompliance Chart & Yes & Regular \\
\hline & Updated indicators & Yes & Regular \\
\hline & They are published & Yes & Regular \\
\hline \multicolumn{4}{|c|}{ Last Planner meetings } \\
\hline \multirow{6}{*}{$35 \%$} & Weekly meeting & Yes & Regular \\
\hline & \begin{tabular}{|l|l} 
Punctuality \\
\end{tabular} & Yes & Poorly \\
\hline & It is done constantly & Yes & Regular \\
\hline & Adequate space & Yes & Regular \\
\hline & The use of radios, cell phones, and computers within the meeting is respected & Yes & Poorly \\
\hline & There is a coffee or cookies for comfort $f$ the participants & No & \\
\hline \multicolumn{4}{|c|}{ Participants } \\
\hline \multirow[b]{2}{*}{$50 \%$} & All participants attend in the meeting & Yes & Good \\
\hline & $\begin{array}{l}\text { There is support in case of staff rotation to take up the subject (inductions, procedures } \\
\text { etc.) }\end{array}$ & No & \\
\hline
\end{tabular}

Figure 2: Example of LPS Maturity worksheet. (Annex A in Baladrón Zanetti, 2017)

\section{Linguistic Action Perspective Indicators}

The authors analyzed LAP indicators, following the methodology proposed by Salazar et al. (2018), later updated by Salazar et al. (2019) and Salazar et al. (2020), known as Weekly Work Planning. The methodology measures positive and negative LAP actions, defined by Retamal et al. (2020). The average of these indicators corresponds to LAP (+) and LAP (-). 
Table 1: Positive and negative linguistic action perspective (LAP) indicators (Table 3 in Retamal et al., 2020)

\begin{tabular}{cc}
\hline LAP indicator & Positive or Negative indicator \\
\hline Arrives on time & Positive \\
Take notes & Positive \\
Check mobile phone & Negative \\
Mobile phone rings & Negative \\
Talk by mobile phone & Negative \\
Leave the room & Negative \\
Walkie talkie rings & Negative \\
Talk by walkie talkie & Negative \\
Does not speak in the meeting & Negative \\
Does not look at the person who is speaking & Negative \\
\hline
\end{tabular}

\section{Notebook for Last Planners}

Video recordings were used in previous research to measure Linguistic Action Perspective (LAP) indicators, but they turned out to be very invasive for the meeting participants. Salazar et al. (2020) propose a way to simplify the measurement of LAP indicators by assigning participants a notebook. This notebook, together with a checklist used by the facilitator, allows researchers to analyze the engagement of the meeting participants, avoiding the use of video recordings. Figure 33 shows the Notebook for Last Planners.

\begin{tabular}{|c|c|c|c|c|c|c|c|c|c|c|c|c|}
\hline \multicolumn{13}{|c|}{ NOTEBOOK FOR LAST PLANNERS } \\
\hline Name & & & & \multirow{3}{*}{\multicolumn{2}{|c|}{$\begin{array}{c}\text { Measureme } \\
\text { Symbology }\end{array}$}} & nt start date: & 1 & 12020 & \multicolumn{2}{|c|}{ Measurement end date: } & \multirow{2}{*}{\multicolumn{2}{|c|}{$\begin{array}{c}1 / 2020 \\
++(\text { Very High) }\end{array}$}} \\
\hline \multirow{2}{*}{$\begin{array}{r}\text { Position: } \\
\text { Company: }\end{array}$} & & & & & & \multirow{2}{*}{\multicolumn{2}{|c|}{\begin{tabular}{|c|}
- (Very low) \\
W: Well \\
\end{tabular}}} & - -(Low) & 0 (Mean) & $+($ High $)$ & & \\
\hline & & & & & & \multicolumn{3}{|c|}{$\mathrm{N}:$ Normal } & \\
\hline & & & Week 2 & \multicolumn{2}{|c|}{ P: Poor } \\
\hline Who asks for it & Activity and / or Task & $(\%)$ & Sector & \begin{tabular}{|l|} 
Day (AM \\
or PM)
\end{tabular} & $\begin{array}{l}\text { Task } \\
\text { Priority }\end{array}$ & $\begin{array}{c}\text { Clarity in } \\
\text { the Petition } \\
\text { (request) }\end{array}$ & \begin{tabular}{|l|}
$\begin{array}{l}\text { Negotiation } \\
\text { and } \\
\text { Agreement }\end{array}$ \\
\end{tabular} & $\begin{array}{c}\% \\
\text { Completed }\end{array}$ & PPC & \begin{tabular}{|c|} 
Declaration \\
of \\
compiance
\end{tabular} & $\begin{array}{c}\text { Declaration } \\
\text { of } \\
\text { satisfaction }\end{array}$ & $\begin{array}{l}\text { Comments } \\
\text { (CNC) }\end{array}$ \\
\hline $\begin{array}{l}\text { Name and / or } \\
\text { Position }\end{array}$ & & & & & $\begin{array}{c}-\because,-, 0,+, \\
++\end{array}$ & W-N-P & $W-N-P$ & $\%$ & \begin{tabular}{|c|} 
Does it \\
comply?
\end{tabular} & Yes - No & Yes - No & \\
\hline Administrator & Floor slab installation - & $80 \%$ & Quadrant A and B & \begin{tabular}{|c|}
$\begin{array}{c}\text { Tuesday } \\
\text { (AM) }\end{array}$ \\
\end{tabular} & - & w & $\mathrm{N}$ & $70 \%$ & NO & YES & NO & bla bla bla \\
\hline & & & & & & & & & & & & \\
\hline & & & & & & & & & & & & \\
\hline & & & & & & & & & & & & \\
\hline & & & & & & & & & & & & \\
\hline & & & & & & & & & & & & \\
\hline & & & & & & & & & & & & \\
\hline & & & & & & & & & & & & \\
\hline & & & Week 2 & & & & & & & Week 3 & & \\
\hline Who asks for it & Activity and / or Task & (\%) & Sector & $\begin{array}{c}\text { Day (AM } \\
\text { or PM) }\end{array}$ & $\begin{array}{l}\text { Task } \\
\text { Priority }\end{array}$ & \begin{tabular}{|c|} 
Clarity in \\
the Petition \\
(request)
\end{tabular} & \begin{tabular}{|c|}
$\begin{array}{c}\text { Negotiation } \\
\text { and } \\
\text { Agreement }\end{array}$ \\
\end{tabular} & $\begin{array}{c}\% \\
\text { Completed }\end{array}$ & PPC & \begin{tabular}{|c|} 
Declaration \\
of \\
compiance
\end{tabular} & \begin{tabular}{|c|}
$\begin{array}{c}\text { Declaration } \\
\text { of } \\
\text { satisfaction }\end{array}$ \\
\end{tabular} & $\begin{array}{c}\text { Comments } \\
\text { (CNC) }\end{array}$ \\
\hline $\begin{array}{c}\text { Name and / or } \\
\text { Position }\end{array}$ & & & & & $\begin{array}{c}-\because,-, 0,+, \\
++\end{array}$ & $W-N-P$ & $W-N-P$ & $\%$ & \begin{tabular}{|c|} 
Does it \\
comply?
\end{tabular} & Yes - No & Yes - No & \\
\hline & & & & & & & & & & & & \\
\hline & & & & & & & & & & & & \\
\hline & & & & & & & & & & & & \\
\hline & & & & & & & & & & & & \\
\hline & & & & & & & & & & & & \\
\hline & & & & & & & & & & & & \\
\hline & & & & & & & & & & & & \\
\hline & & & & & & & & & & & & \\
\hline
\end{tabular}

Figure 3: Notebook for Last Planners. (Appendix B in Salazar et al., 2020)

\section{RESEARCH TASKS}

Due to the COVID-19 pandemic, the authors participated in Weekly Work Planning meetings via videoconference for each project. These meetings were held every week for 
a total of 10 weeks. In weeks 1 and 8, the researchers measured the LPS maturity level to analyze the evolution of the project, using the LIP implementation strategy detailed below.

1. Kick-off meeting: A kick-off meeting was held to detail the scope of the research for the selected projects. In each project, a field facilitator was defined, while the researcher participated via videoconference. The role of the facilitator was to support the implementation tasks that the researcher assigned during the kick-off videoconference. Specifically, the field facilitator was provided with the necessary materials, problems with the internet connection were resolved, and, in the case that the facilitator does not understand all simulations, they were explained. In addition, every Friday for the next 10 weeks, the researcher met with all project facilitators by video call to check on the progress of each project and explain the activities to be carried out in the following week.

2. Diagnosis and baseline: Information regarding each project's history was collected to determine the context. During the first week, the level of LPS maturity and LAP indicators were initially evaluated, and the information about the PPC was collected prior to the intervention to serve as a point of comparison with the implementation.

3. Implementation: During weeks 1 to 5, three simulations with the planners were run online. In addition, each week, a short presentation was made on LAP. These presentations did not last more than ten minutes per week to avoid interfering with the meeting times. The agenda for each of the first five weeks is shown in Tabl; agendas were chosen so that the simulations share a common thread with that week's presentations.

Table 2: Timeline of intervention in the first five weeks

\begin{tabular}{ccccccc}
\hline Measure & Week 1 & Week 2 & Week 3 & Week 4 & Week 5 & Week 8 \\
\hline Intervention & $\begin{array}{c}\text { What } \\
\text { does LAP } \\
\text { mean? }\end{array}$ & $\begin{array}{c}\text { Importance of } \\
\text { Commitment } \\
\text { Management }\end{array}$ & Moods & Team Work & $\begin{array}{c}\text { Conditions of } \\
\text { Satisfaction and } \\
\text { background of } \\
\text { obviousness }\end{array}$ & \\
Simulation & & Dice Game & & Nasa on & $\begin{array}{c}\text { Dictation } \\
\text { Drawing }\end{array}$ & \\
Measurement & PPC / & PPoon & & & PPC / LPS \\
& Maturity & & PPC & & & Maturity \\
\hline
\end{tabular}

4. Tracing and checking: During weeks 6 to 8, each Last Planner participant entered their information in the LAP notebook. In addition, the researcher was present in each meeting via videoconference to receive an update regarding how the commitments were developing. In week 8, the LPS maturity level was measured again to establish metrics before and after the intervention.

5. Evaluation and improvement process: The evaluation was carried out by analyzing the evolution of the LPS maturity level, the increase in commitment management when using LAP, and the PPC stabilization. Finally, a new method for performing interventions online was established, with only facilitators being allowed in the field because of the constraints of the pandemic. 


\section{RESULTS AND ANALYSIS}

Due to the pandemic, the authors held a videoconference each week to see how the commitments were being carried out. The facilitators then printed an LPS notebook for each of the workers who were at the LPS meeting.

With the LPS notebook, the following results were obtained in weeks 1, 5, and 8 for each project, detailing information about the indicators proposed by Salazar et al. (2020). The positive and negative LAP indicators were measured by the field facilitators because the researchers' webcam did not capture all the people in the meeting. These positive (+) and negative (-) LAP indicators are described in Table 1.

In addition, the level of maturity was measured by the authors, using their expertise, to prevent the facilitators from reporting subjective opinions. Table 33 shows the results obtained and the slope of the trend line from the four projects that were measured in these eight weeks.

Table 3: Results of indicators in each project

\begin{tabular}{|c|c|c|c|c|c|}
\hline Project & Indicator & Week 1 & Week 5 & Week 8 & Slope \\
\hline \multirow{8}{*}{ A } & PPC & $72.73 \%$ & $65.91 \%$ & $88.89 \%$ & $2.7 \%$ \\
\hline & $\operatorname{LAP}(+)$ & $63.33 \%$ & $70.59 \%$ & $81.25 \%$ & $1.1 \%$ \\
\hline & LAP (-) & $0.83 \%$ & $5.88 \%$ & $7.81 \%$ & $0.8 \%$ \\
\hline & LPS & $43.00 \%$ & - & $64.00 \%$ & $3.0 \%$ \\
\hline & $\%$ of fulfillment of a request & $67.42 \%$ & $56.25 \%$ & $83.33 \%$ & $2.0 \%$ \\
\hline & $\%$ of compliance negotiation and agreements & $56.06 \%$ & $62.50 \%$ & $83.33 \%$ & $3.8 \%$ \\
\hline & $\begin{array}{c}\% \text { of declaration of compliance with the } \\
\text { commitment }\end{array}$ & $38.33 \%$ & $50.00 \%$ & - & $2.9 \%$ \\
\hline & $\%$ of fulfillment declaration of satisfaction & $53.33 \%$ & $25.00 \%$ & - & $-7.1 \%$ \\
\hline \multirow{8}{*}{ B } & PPC & $64.41 \%$ & $89.36 \%$ & $81.63 \%$ & $2.8 \%$ \\
\hline & $\operatorname{LAP}(+)$ & $90.00 \%$ & $86.36 \%$ & $100.00 \%$ & $2.7 \%$ \\
\hline & LAP (-) & $11.67 \%$ & $9.09 \%$ & $5.83 \%$ & $-0.9 \%$ \\
\hline & LPS & $68.00 \%$ & - & $76.00 \%$ & $1.1 \%$ \\
\hline & $\%$ of fulfillment of a request & $86.51 \%$ & $77.78 \%$ & $94.61 \%$ & $1.0 \%$ \\
\hline & $\%$ of compliance negotiation and agreements & $52.38 \%$ & $70.37 \%$ & $94.76 \%$ & $6.0 \%$ \\
\hline & $\begin{array}{c}\% \text { of declaration of compliance with the } \\
\text { commitment }\end{array}$ & $75.79 \%$ & $90.29 \%$ & $98.33 \%$ & $3.2 \%$ \\
\hline & $\%$ of fulfillment declaration of satisfaction & $75.79 \%$ & $88.29 \%$ & $98.15 \%$ & $3.2 \%$ \\
\hline \multirow{8}{*}{$\mathrm{C}$} & PPC & $55.00 \%$ & $59.25 \%$ & $58.00 \%$ & $-0.2 \%$ \\
\hline & $\operatorname{LAP}(+)$ & $56.25 \%$ & $65.63 \%$ & $67.65 \%$ & $1.4 \%$ \\
\hline & LAP (-) & $2.34 \%$ & $7.81 \%$ & $5.88 \%$ & $0.7 \%$ \\
\hline & LPS & $59.00 \%$ & - & $71.00 \%$ & $1.7 \%$ \\
\hline & $\%$ of fulfillment of a request & $57.41 \%$ & $66.67 \%$ & $66.67 \%$ & $1.4 \%$ \\
\hline & $\%$ of compliance negotiation and agreements & $49.07 \%$ & $50.00 \%$ & $50.00 \%$ & $0.1 \%$ \\
\hline & $\begin{array}{c}\% \text { of declaration of compliance with the } \\
\text { commitment }\end{array}$ & $59.44 \%$ & $100.00 \%$ & $91.67 \%$ & $4.9 \%$ \\
\hline & $\%$ of fulfillment declaration of satisfaction & $51.11 \%$ & $100.00 \%$ & $91.67 \%$ & $6.1 \%$ \\
\hline
\end{tabular}




\begin{tabular}{cccccc}
\hline Project & Indicator & Week 1 & Week 5 & Week 8 & Slope \\
\hline PPC & $71.88 \%$ & $77.78 \%$ & $75.68 \%$ & $-0.6 \%$ \\
LAP (+) & $86.67 \%$ & $100.00 \%$ & $84.62 \%$ & $-0.1 \%$ \\
LAP (-) & $3.33 \%$ & $0.83 \%$ & $0.00 \%$ & $-0.5 \%$ \\
LPS & $47.00 \%$ & - & $73.00 \%$ & $3.7 \%$ \\
D & $\%$ of fulfillment of a request & $62.50 \%$ & $75.00 \%$ & $60.71 \%$ & $-0.1 \%$ \\
& $\%$ of compliance negotiation and agreements & $50.00 \%$ & $63.54 \%$ & $60.71 \%$ & $1.6 \%$ \\
& $\%$ of declaration of compliance with the & $74.31 \%$ & $90.48 \%$ & $95.24 \%$ & $3.0 \%$ \\
commitment & & & & \\
& $\%$ of fulfillment declaration of satisfaction & $74.31 \%$ & $90.48 \%$ & $95.24 \%$ & $3.0 \%$ \\
\hline
\end{tabular}

The results show that during the first five weeks of intervention, there was an increase in LAP (+) in three out of four projects. This is because this intervention begins with LA prompts. However, regarding LAP (-) indicators, we observed different results.

In week 8 , we can see that over the long term, the authors suggested continuous improvements during each intervention, which projects may or may not implement. In some cases, the LAP $(+)$ indicators continued to increase, as was the case for projects A, $\mathrm{B}$, and $\mathrm{C}$, who implemented continuous improvements in their projects with respect to better behavior exhibited by workers during the weekly work planning meeting (WWP).

In terms of the indicators proposed by Salazar et al. (2020) regarding the linguistic action perspective, the trend line shows that in the long term, these indicators increased for all projects, demonstrated by their positive slopes. Furthermore, in week 8 for project $\mathrm{A}$, we can see that some indicators were not measured by the workers, causing a $-7.1 \%$ slope for the percentage of fulfillment declaration of satisfaction. However, in this case, as it does not have three measurements, it is eliminated from the indicator analysis.

In terms of PPC variation, the commitments increased during the weeks that all linguistic action indicators were increased; in other words, the higher the PPC, the higher the results from the LAP. In addition, there was PPC stabilization, preventing large variations in this indicator for each project.

Finally, the Last Planner maturity level was reinforced by the intervention carried out during each of the projects. For all projects, the maturity level increased by $11 \%$, especially in projects A and D. For projects A and D, we also see that an increase in PPC as well as a gradual increase in LAP indicators.

\section{CONCLUSIONS}

The intervention during these five weeks led to an increase in the maturity level of the Last Planner® System, creating a new method for performing remote interventions. This method's use of videoconferences was especially effective, since they ensured that those participating in all projects understood the linguistic action process. Furthermore, the interventions were recorded on video so that all projects could access them and the knowledge they contained.

Regarding the positive LAP indicators and the indicators proposed by Salazar et al. (2020), we conclude that by performing remote interventions focused on the linguistic action perspective, it is possible to increase the knowledge of the Last Planners and establish reliable commitments during the eight weeks of monitoring, and that these lessons can be replicated in both the current and future projects. With the LAP notebook, we found that the Last Planners became more involved in the project since, during each 
weekly work plan meeting, they themselves provide their perception of how different commitments are being carried out.

As this research used a small sample and followed up for eight weeks, it is recommended that the measurements last longer to determine whether there is continuous project improvement.

This research demonstrated that online interventions can be achieved from anywhere in the world, overcoming existing social distancing limitations due to COVID-19 or any other potential cause. By doing so, this study demonstrates a new way of generating value through distance. Nevertheless, the facilitators for each project played an important role in these interventions.

In the future, the authors plan to continue looking for new patterns, both by adding more variables and generating more data; significant sample information regarding the evolution of these projects will produce more reliable results.

\section{ACKNOWLEDGMENTS}

We thank GEPUC and INGECO for their support in this research. Additionally, Luis A. Salazar acknowledges the financial support for his PhD studies from the Scholarship Programme of Conicyt Chile (ANID-PCHA/National Doctorate/2016-21160819).

\section{REFERENCES}

Austin, J. L. (1971). Palabras y Acciones. Paidós. Buenos Aires.

Babalola, O., Ibem, E. O., \& Ezema, I. C. (2019). Implementation of lean practices in the construction industry: A systematic review. Building and Environment, 148, 34-43. doi.org/10.1016/j.buildenv.2018.10.051.

Baladrón Zanetti, C. (2017). Evaluación de impactos de la implementación de metodologías lean en proyectos de desarrollo minero en construcción (Pontificia Universidad Católica de Chile). Retrieved from https://repositorio.uc.cl/handle/11534/21415.

Ballard, G., \& Tommelein, I. (2016). Current Process Benchmark for the Last Planner System. Lean Construction Journal, 13(1), 57-89. Retrieved from https://leanconstruction.org.uk/wp-content/uploads/2018/10/Ballard_Tommelein2016-Current-Process-Benchmark-for-the-Last-Planner-System.pdf.

Eastman, C., Teicholz, P., Sacks, R., \& Liston, K. (2011). BIM Handbook: A Guide to Building Information Modeling for Owners, Managers, Designers, Engineers and Contractors. John Wiley \& Sons.

Flores, F. (2015). Conversaciones para la Acción. Bogotá, D.C., Colombia: Lemoine Editores.

Goldratt, E. M., \& Cox, J. (2013). La meta, un proceso de mejora continua. In S. A. Ediciones Granica (Ed.), Revisada. 12a. Reimp. Granica. México (Tercera). México D.F.

Gómez-Cabrera, A., Salazar, L. A., Ponz-Tienda, J. L., \& Alarcón, L. F. (2020). Lean Tools Proposal to Mitigate Delays and Cost Overruns in Construction Projects. Proc. 28th Annual Conference of the International Group for Lean Construction (IGLC), 781-792. doi.org/10.24928/2020/0049.

Macomber, H., \& Howell, G. A. (2003). Linguistic Action: Contributing to the theory of lean construction. Proc. 11th Annual Meeting of the International Group for Lean Construction. Virginia, USA. 
McKinsey \& Company. (2009). Productividad como motor de crecimiento: El próximo desafío = Chile X 2. Presentación Ante La Confederación de La Producción y El Comercio de Chile, 38. Santiago, Chile.

Retamal, F., Salazar, L. A., Herrera, R. F., \& Alarcón, L. F. (2020). Exploring the Relationship Among Planning Reliability (PPC), Linguistic Action Indicators and Social Network Metrics. In I. D. Tommelein \& E. Daniel (Eds.), Proc. $28^{\text {th }}$ Annual Conference of the International Group for Lean Construction (IGLC) (pp. 109-118). doi.org/10.24928/2020/0031.

Salazar, L. A., Arroyo, P., \& Alarcón, L. F. (2020). Key Indicators for Linguistic Action Perspective in the Last Planner® System. Sustainability, 12(20), 8728. doi.org/10.3390/su12208728.

Salazar, L. A., Ballard, G., Arroyo, P., \& Alarcón, L. F. (2018). Indicators for Observing Elements of Linguistic Action Perspective in Last Planner® System. In V. A. González (Ed.), Proc. 26 ${ }^{\text {th }}$ Annual Conference of the International. Group for Lean Construction (IGLC) (pp. 402-411). doi.org/10.24928/2018/0441.

Salazar, L. A., Retamal, F., Ballard, G., Arroyo, P., \& Alarcón, L. F. (2019). Results of indicators from the linguistic action perspective in the Last planner® system. $27^{\text {th }}$ Annual Conference of the International Group for Lean Construction, IGLC 2019, 1241-1250. doi.org/10.24928/2019/0148.

Searle, J. R. (1969). Speech acts: An essay in the philosophy of language (Vol. 626). Cambridge university press.

Vujica Herzog, N., \& Tonchia, S. (2014). An Instrument for Measuring the Degree of Lean Implementation in Manufacturing. Strojniški Vestnik - Journal of Mechanical Engineering, 60(12), 797-803. doi.org/10.5545/sv-jme.2014.1873.

Yacuzzi, E. (2005). El estudio de caso como metodología de investigación: Teoría, mecanismos causales, validación. Buenos Aires.

Yin, R. K. (2003). Case Study Research: Design and Methods. In SAGE Publications ( $^{\text {th }}$ ed.). Thousand Oaks, CA. 